УДК 351:001.5+008

DOI: https://doi.org/10.54929/pmtl-issue1-2021-11

\title{
ФОРМУВАННЯ ПОТЕНЦІАЛУ ПУБЛІЧНО-ПАРТНЕРСЬКОЇ ВЗАЄМОДІЇ В СИСТЕМІ ПУБЛІЧНОГО УПРАВЛІННЯ
}

\author{
FORMATION OF POTENTIAL OF PUBLIC-PARTNERSHIP \\ INTERACTION IN THE SYSTEM OF PUBLIC MANAGEMENT
}

\author{
Михайловська О. В. \\ кандидат економічних наук, доцент, \\ доцент кафедри публічного управління \\ та менеджменту організацій, НУ «Чернігівська політехніка» \\ ORCID: 0000-0002-7682-2292 \\ Olena Mykhailovska \\ Candidate of Economic Sciences, Associate Professor, \\ Associate Professor at the Department of Public Administration \\ and Organizations` Management, \\ Chernihiv Polytechnic National University
}

У статті досліджено напрями розвитку взаємодії між державою та суспільством в системі публічного управління та актуалізовано питання про пошук шляхів формування потенціалу взаємодії між державою та суспільством. Доведено необхідність побудови концептуальної основи публічно-партнерської взаємодії між органами державного управління, місцевого самоврядування та інститутами громадянського суспільства на партнерських засадах. Схарактеризовано наукові погляди щодо тлумачення поняття «громадянське суспільство». Зауважено, що становлення громадянського суспільства виявляється у фрормуванні та ффункціонуванні його інститутів. Представлено результати дослідження законодавчо-нормативного поля відносно сутності поняття «інститути громадянського суспільства» та його розмежування з іншими поняттями. Наведено місце інститутів громадянського суспільства у соціальній системі. Розкрито важливість інститутів громадянського суспільства у практичному вимірі фрункціонування системи публічного управління. Ідентифріковано сутність поняття «потенціал публічно-партнерської взаємодії» та виокремлено його складові елементи. З'ясовано, що наявні погляди науковців щодо трактування категорії «потенціал» не суперечать один одному і $\epsilon$ взаємодоповнюючими. Виокремлено ключові характеристики потенціалу в системі публічного управління. Сфрормована основа публічно-партнерської взаємодії та визначені напрями забезпечення їі ефрективності. Ключові слова: публічне управління, взаємодія, потенціал, розвиток, партнерство, громадянське суспільство.

В статье исследованы направления развития взаимодействия между государством и обществом в системе публичного управления. Актуализирован вопрос о поиске путей формирования потенциала взаимодействия между государством и обществом. Установлено, что до сих пор не выработано единого видения по эфрфективному использованию потенциала взаимодействия государства и общества в системе публичного управления. Доказана необходимость построения концептуальной основы публично-партнерского взаимодействия между органами государственного управления, местного самоуправления и институтами гражданского общества на партнерских началах. Характеризированы научные взгляды относительно толкования понятия «гражданское общество». Представлены результаты исследования законодательно-нормативного поля относительно сущности понятия «институты гражданского общества» и его разграничение с другими понятиями. Определено место институтов гражданского общества в социальной системе. Отмечена необходимость взаимодействия институтов гражданского общества между собой. Раскрыта важность институтов гражданского общества в практическом измерении ффункционирования системы публичного управления. Идентифицирована сущность понятия «потенциал публично-партнерского взаимодействия» и выделены его составляющие элементы. Выделены ключевые характеристики потенциала в системе публичного управления. Сформирована основа публично-партнерского взаимодействия и определены направления обеспечения ее эффрективности. 
Ключевые слова: публичное управление, взаимодействие, потенциал, развитие, партнерство, гражданское общество.

The article investigates the directions of development of interaction between the state and society in the system of Public Management. The issue of finding ways to form the potential for interaction between the state and society has been raised. The interaction of civil society and the state is recognized as a determining factor in ensuring the democratic development of the country. It is established that so far no common vision has been developed on the effective use of the potential for interaction between the state and society in the system of Public Management. The necessity of building a conceptual basis of public-partnership interaction between public administration, local self-government and civil society institutions on a partnership basis is proved. Scientific views on the interpretation of the concept of "civil society" are characterized. It is noted that the formation of civil society is manifested in the formation and functioning of its institutions. The results of the research of the legislative and normative field concerning the essence of the concept of "civil society institutions" and its delimitation with other concepts are presented. The place of civil society institutions in the social system is determined. The necessity of interaction of civil society institutions with each other is noted. The importance of civil society institutions in the practical dimension of the functioning of the Public Management system is revealed. The essence of the concept of "potential of public-partnership interaction" is identified and its constituent elements are singled out. It was found that the current views of scientists on the interpretation of the category "potential" do not contradict each other and are complementary. The key characteristics of the potential in the system of Public Management are singled out. It has been noted that inefficiency of reform processes is connected with uncertainty and instability of forms of communication between the authorities and the public. The basis of public-partnership interaction is formed and the directions of ensuring its efficiency are determined.. Key words: public administration, interaction, potential, development, partnership, civil society.

Постановка проблеми. Одним із ключових аспектів сучасної управлінської науки, що вимагає прискіпливої уваги, виступає процес розвитку взаємовідносин між державою та суспільством в системі публічного управління, оскільки сучасні трансформаційні процеси в Україні посилюють невизначеність зовнішнього середовища та здатні знизити ефективність публічного управління. Зазначене актуалізує питання пошуку шляхів формування, розвитку та використання потенціалу взаємодії між державою та суспільством. Тобто взаємодія громадянського суспільства й держави цілком справедливо вважається визначальним фактором у забезпеченні демократичного розвитку країни.

Аналіз останніх досліджень і публікацій. Дослідженню теоретичних, а також практичних питань формування та розвитку потенціалу соціально-економічних систем присвячено праці багатьох учених, зокрема таких як: Л. Абалкін, О. Алімов, В. Архангельський, Р. Симіонов та інші. Окремим аспектам потенціалу публічного управління присвятили свої роботи О. Халепа, В. Васютинський, В. Вербець (розглядають питання щодо ефективних форм сучасної взаємодії в публічній сфері); Л. Даниленко, В. Московець, Ф. Рудич, Г. Щедрова (досліджують проблемні питання громадянського суспільства в сучасній Україні); О. Бажинова, О. Кучабський, Я. Собаків (приділяють увагу ключовим засадам взаємодії в системі публічного управління) І. Письменний (досліджує та аналізує синергетичний потенціал публічного управління) та інших. Водночас у науковій літературі більш дослідженим залишається потенціал саме економічних систем. Також, дотепер не вироблено єдиного бачення щодо ефективного використання потенціалу взаємодії держави та суспільства в системі публічного управління.
Виділення невирішених раніше частин загальної проблеми, котрим присвячується означена стаття. В науці публічного управління продовжується пошук дієвих управлінських механізмів, які б синтезували вже сфрормовані підходи. Досвід розвинених країн демонструє необхідність розвитку взаємодії в системі публічного управління, що сприяло б накопиченню та використанню наявного потенціалу. Зазначене, спонукає до побудови концептуальної основи публічно-партнерської взаємодії між органами державного управління, місцевого самоврядування та інститутами громадянського суспільства за напрямом зміцнення зв'язків між всіма підсистемами.

Формулювання цілей статті (постановка завдання). Метою даної статті $€$ дослідження шляхів формування потенціалу взаємодії в системі публічного управління.

Виклад основного матеріалу дослідження. Відзначаючи цінність та значущість наукових опрацьовувань у галузі публічного управління, зазначимо, що в умовах становлення його інститутів необхідно більш ґрунтовно дослідити найвагомішу складову даної системи - громадянське суспільство. Отже, зупинимося на деяких визначеннях:

1) «соціальна спільнота» - «сукупність людей, об'єднаних відносно стійкими соціальними зв'язками, відносинами, яка має загальні ознаки, що надають їй неповторної своєрідності» [1]; «група людей, яка склалася об'єктивно в процесі історичного розвитку, реально існує, практично фріксується, характеризується відносною цілісністю і виступає самостійним суб'єктом соціальної та історичної дії» [2].

2) «суспільство» у звичайному розумінні - «сукупність мешканців певної країни, організована соціальна спільнота, яка характеризується доволі високим ступенем єдності, почуттям своєї відмін- 
ності від ін. спільнот такого роду, існує достатньо висока інтенсивність взаємного впливу між її членами, поєднаними між собою подібністю умов життя, поділом праці, нормами поведінки» [3].

3) У Білій книзі врядування Європейського Союзу (ЄС) зазначено: «Громадянське суспільство об'єднує переважно організації, самоутворені або утворені під керівництвом, організації неурядові, професійні асоціації, харитативні, ініціативні, організації, що заохочують до соціально активного життя на рівні району й міста, часом із внеском місцевої церкви та її громади» [4].

Поряд із наведеними тлумаченнями існує велика кількість інших поглядів щодо розуміння поняття «громадянське суспільство» аналіз яких дозволяє дійти висновку про те, що найкраще розкриває його зміст наступне визначення: «це суспільство зрілих громадян із високим рівнем економічної, соціальної, духовної, політичної культури, яке спільно з державою утворює розвинені правові відносини. Це суспільство вільних громадян, яке вільне від держави, але взаємодіє з нею заради спільного блага» [5]. Цікавою також варто визнати думку Д. Дьюї, за якою громадськість - «це активне соціальне утворення, що в певний момент об'єднує всіх тих, хто стикається зі спільною проблемою і може разом шукати шляхи її розв'язання». 3 точки зору теорії Паблик рилейшнз громадськістю можна вважати лише активну групу чи окремих індивідів [6].

Водночас на думку Г. Щедрової, з якою погоджується авторка, становлення громадянського суспільства виявляється у формуванні та функціонуванні його інститутів (політичних партій, громадських організацій, груп інтересів, органів місцевого самоврядування, недержавних 3МІ тощо) [7]. Тож, окрему увагу варто приділити поняттю «інститути громадянського суспільства» (ІГС), життєдіяльність яких закладається в підґрунтя демократичного суспільства. Науковці, зазвичай, зі сферою суспільних інститутів і відносин ототожнюють громадянське суспільство [8], однак сам термін має декілька значень: це суб'єкти, які в процесі свої діяльності формують суспільні відносини, спрямовані на утвердження громадянського суспільства [9]; це інститути, які об'єднують у своєму складі норми конституційного та інших галузей права, що регулюють суспільні відносини у відповідній сфрері й виступають складовими елементами багатовимірної системи конституційного права України [10]; це загальна назва для всіх упорядкованих і структурованих виявів громадянського суспільства тощо [11]. На рис. 1 представлено результати дослідження законодавчо-нормативного поля відносно сутності поняття «інститути громадянського суспільства» та його розмежування з іншими поняттями. Варто наголосити, що дискусії навколо складових елементів інститутів громадянського суспільства та законодавчого закріплення цього поняття досі $є$ актуальними у наукових колах.

Підсумовуючи вищенаведене, візуалізуємо отримані результати (рис. 2).

В умовах швидких змін так само швидко змінюється і модель управління в державі, а також управління різними сферами й процесами. Проблема взаємодії в системі публічного управління також загострюється. У такому випадку діяльність інститутів громадянського суспільства має бути пов'язана з трансформацією звичайних взаємовідносин у взаємодію. Наголосимо, що інститути громадянського суспільства для підвищення ефективності діяльності мають взаємодіяти не лише з органами влади, а й між собою (Рис. 3).

Отже, у практичному вимірі фрункціонування системи публічного управління інститути громадянського суспільства відіграють ключову роль, оскільки виступають з'єднуючою ланкою між визначенням потреб й інтересів громадянського суспільства та формуванням державної політики. У такому розрізі політика держави виступає своєрідною реакцією на потреби громадянського суспільства, а тому її найкраще реалізувати шляхом побудови дієвої взаємодії між владними структурами та громадянським суспільством.

Водночас варто враховувати, що наголос лише на формальних утвореннях інститутів громадянського суспільства не є об'єктивним, оскільки поза увагою залишаються неформальні групи, що поєднані спільними інтересами. 3 цього приводу доречною є думка Д. Груніга [6], який наголошує на факторах ситуативного характеру, які завдяки комунікації та спілкуванню людей між собою перетворюють латентну (приховану) громадськість на активну: 1) усвідомлення проблеми (демонструє, якою мірою люди відчувають зміни в певній ситуації і тим самим усвідомлюють потребу в інформації); 2) усвідомлення обмежень (засвідчує, в якій мірі люди відчувають себе утиснутими під дією визначених факторів та намагаються знайти шляхи виходу з конкретної проблемної ситуації, що склалася); 3) рівень включеності (демонструє до якого ступеня люди бачать себе «втягнутими» в проблемну ситуацію та відчувають ії̈ вплив на себе) [13].

Для ідентифікації сутності поняття «потенціал публічно-партнерської взаємодії», а також виокремлення його складових елементів виникає потреба розглянути існуючі підходи до визначення дефініції «потенціал». Зауважимо, що в теорії управління термін «потенціал» трактується неоднозначно. Деякі науковці припускають, що термін «потенціал» походить: від французького «potentiel» і використовується у значенні «можливий, або той, що може бути»; від латинського «potentia», що означає приховану можливість, необхідну силу для досягнення певних цілей. 

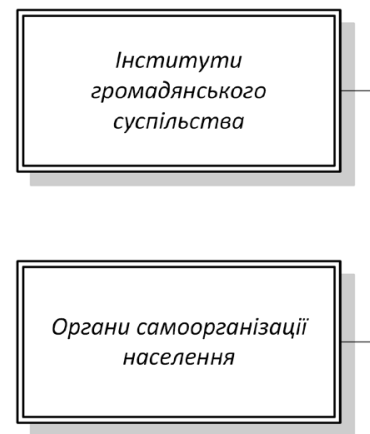

Закон України

Про органи самоорганізації населення (Відомості Верховної Ради України (ВВР), 2001, № 48, ст. 254) громадської експертизи діяльності органів виконавчої влади, затвердженого постановою Кабінету Міністрів
Порядок сприяння проведенню України від 5 листопада 2008 р. №

.........976..........

Закон України

Територіальна громада Про місцеве самоврядування в Україні (Відомості Верховної Ради України (ВВР), 1997, № 24, ст.170)

\section{Закон України}

Громадські об'єднання Про громадські об'єднання (Відомості Верховної Ради України (ВВР), 2013, № 1, ст.1) до інститутів громадянського суспільства віднесено: громадські організації, професійні та творчі спілки, організації роботодавців, благодійні і релігійні організації, органи самоорганізації населення, недержавні засоби масової інформації та інші непідприємницькі товариства і установи, легалізовані відповідно до законодавства.
Орган самоорганізації населення є однією з форм участі членів територіальних громад сіл, селищ, міст, районів у містах у вирішенні окремих питань місцевого значення.

Органами самоорганізації населення є будинкові, вуличні, квартальні комітети комітети мікрорайонів, комітети районів у містах, сільські, селищні комітети.

Органи самоорганізації населення - представницькі органи, що створюються частиною жителів, які тимчасово або постійно проживають на відповідній території в межах села, селища, міста

Територіальна громада - жителі, об'єднані постійним проживанням у межах села, селища, міста, що є самостійними адміністративно-територіальними одиницями, або добровільне об'єднання жителів кількох сіл, селищ, міст, що мають єдиний адміністративний центр.

Система місцевого самоврядування включає: територіальну громаду; сільську, селищну, міську раду; сільського, селищного, міського голову; виконавчі органи сільської, селищної, міської ради; старосту.

Громадське об'єднання - це добровільне об'єднання фізичних осіб та/або юридичних осіб приватного права для здійснення та захисту прав і свобод, задоволення суспільних, зокрема економічних, соціальних, культурних, екологічних, та інших інтересів.

Громадське об'єднання за організаційно-правовою формою утворюється як громадська організація або громадська спілка.

\section{Рис. 1. Законодавчо-нормативна база щодо розмежування понять «інститути громадянського суспільства», «органи самоорганізації населення», «громадські об'єднання», «територіальні громади»}

Джерело: побудовано авторкою[12]

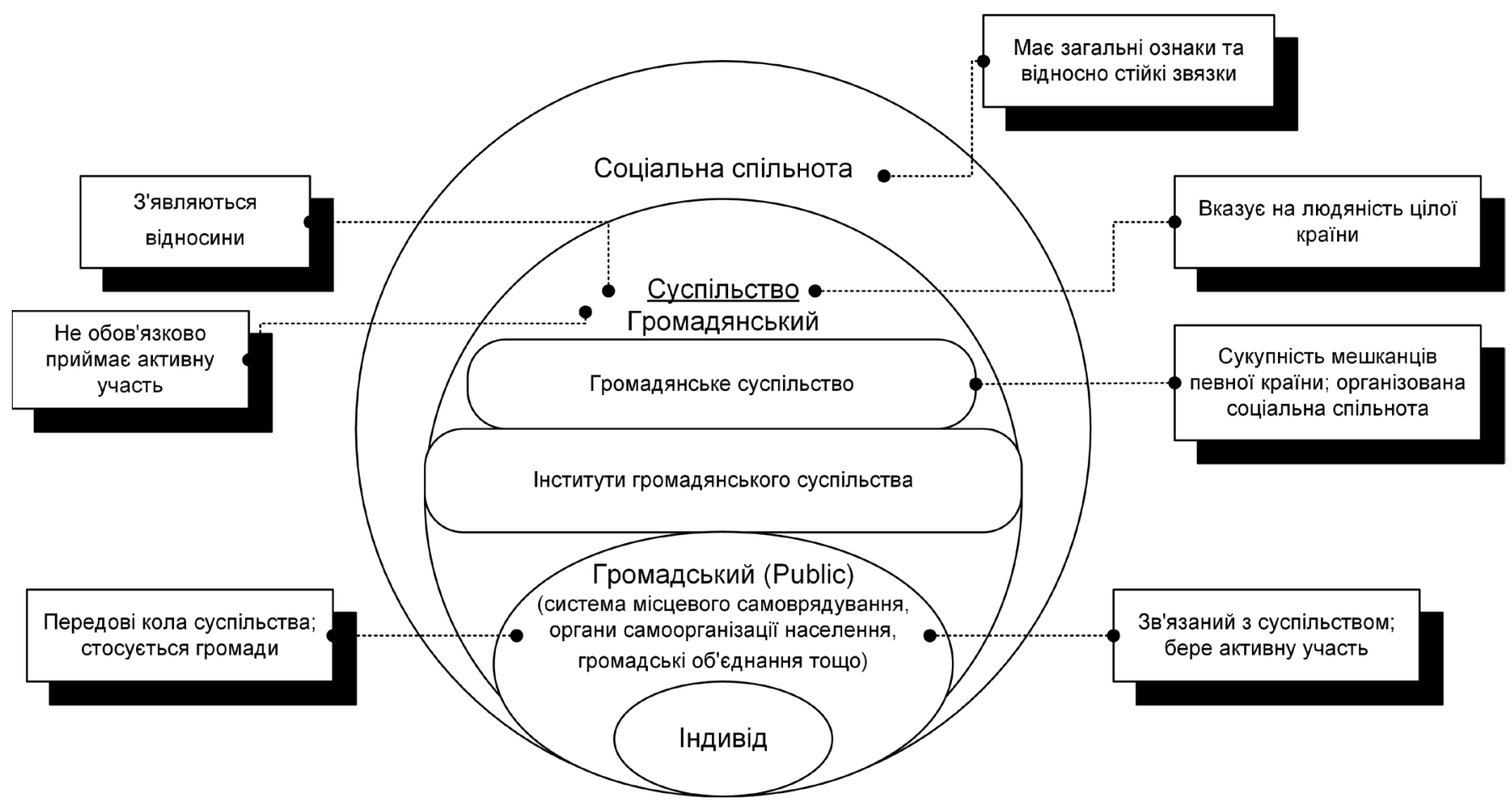

Рис. 2. Місце інститутів громадянського суспільства у соціальній системі

Джерело: побудовано авторкою[12]

Зауважимо, що ґрунтовне дослідження сутності потенціалу в системі публічного управління було представлено в роботах І. Письменного [14], який виокремлює три рівні зв'язків і відносин поняття «потенціал»: 1) відображення минулого; 2) рецензування сьогодення; 3) орієнтація на майбутнє. У наукових роботах також сформовані специфрічні характеристики поняття «потенціал»: 1) потенціал 


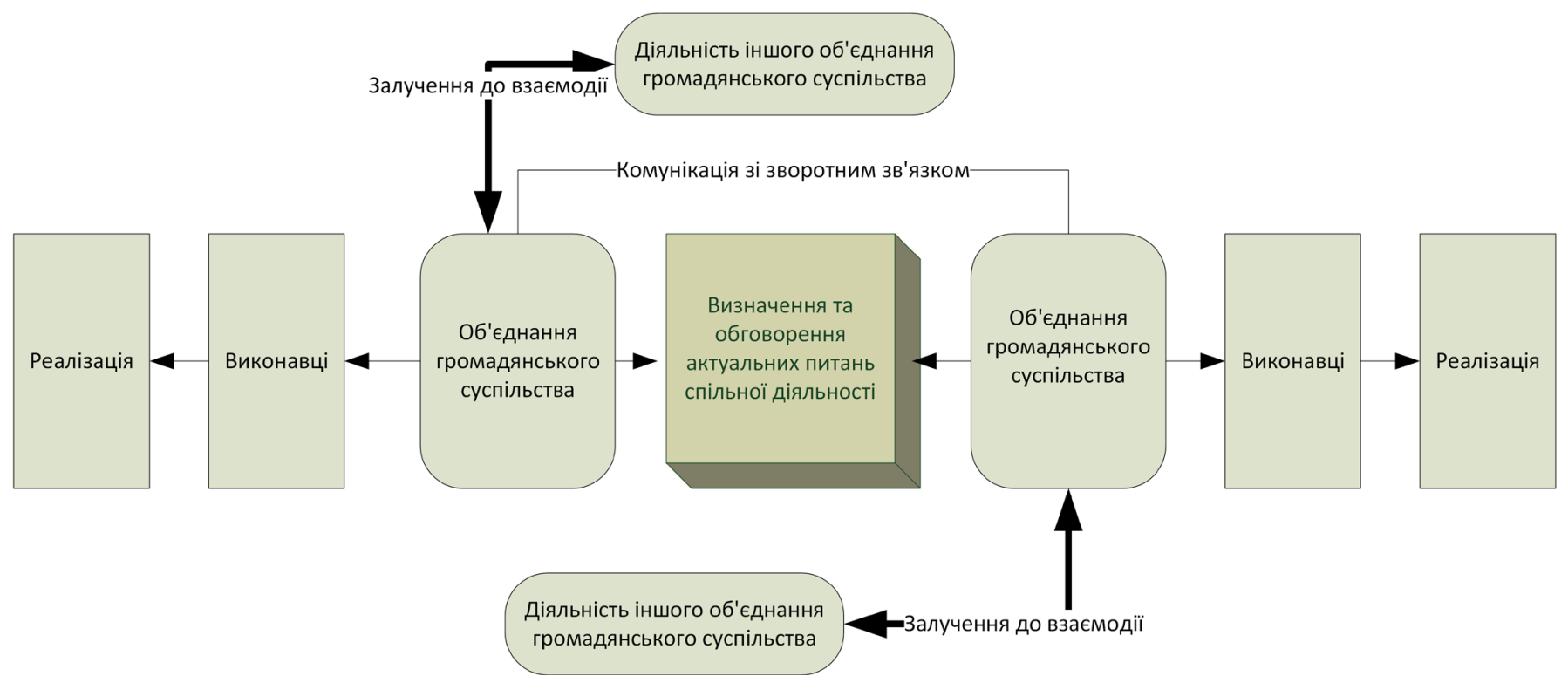

Рис. 3. Система взаємодії інститутів громадянського суспільства

Джерело: побудовано авторкою[12]

$€$ динамічною категорією; 2) сутність і зміст потенціалу полягає в інтеграційному відображенні поточних і майбутніх можливостей системи трансорормувати вхідні ресурси у певні блага; 3) використання потенціалу повинно супроводжуватися його зростанням; 4) процеси використання та нарощення потенціалу є безперервними. Водночас наявність ресурсної бази у складі потенціалу та її ефективного використання, не гарантує корисності для взаємодії у системи публічного управління.

Безперечно, наявні погляди науковців щодо трактування категорії «потенціал» не суперечать один одному і є взаємодоповнюючими. Тому, підкреслимо наступне: потенціал взаємодії не можна розглядати як формалізоване або статичне явище, оскільки він має певну ієрархію структурних елементів, які можуть вступати у специфічні зв'язки між собою і проявляються як інші потенціали; потенціал взаємодії у певному часовому інтервалі характеризується масштабами, рівнем та мірою перетворення у певний результат; ступінь перетворення потенційного в реальне залежить від кількості причин та наявних умов, а також величини накопичених резервів і можливостей; потенціал взаємодії не є простою сукупністю ресурсів їх резервів і можливостей, вони мають бути поєднані певним чином задля досягнення визначених цілей.

Варто наголосити, що неефективність реформаційних процесів у пострадянських країнах теоретики та практики часто пов'язують з невизначеністю та неусталеністю фрорм саме комунікаційної взаємодії між органами влади та громадськістю, які мали стати об'єднуючою платформою. Водночас підвищення ефективності державного управління пов'язується з оптимізацією форм комунікаційної взаємодії та формуванням єди- ного комунікативного простору. В Україні за роки незалежності непродумане рефрормування деформувало уявлення про нього, що призводило до втрати можливості створювати еволюцію взаємодії на різних рівнях публічного управління.

Сучасні тенденції розвитку нашої країни вимагають наукового обґрунтування закономірностей управління взаємодією в системі публічного управління. Виникає необхідність формуваннянової парадигми взаємодії суб'єктів публічного управління, що враховує впливи зовнішнього середовища, які обмежують повноцінне функціонування публічної системи. У такому фокусі основа фрормування публічно-партнерської взаємодії може бути представлена у вигляді рис. 4.

Зазначимо, що публічно-партнерська взаємодія може відбуватися у різних напрямах: тристороння взаємодія; будь-які напрями двосторонньої взаємодії. Наголосимо, що ефективно виконувати свої фрункції публічна влада може лише за умови належної взаємодії з системою громадянського суспільства. Тут доречною $€$ позиція А. Бажинової, яка наголошує на тому, що «громадянське суспільство не залежить від держави, але взаємодіє з нею заради загального блага» [15]. Отже, під потенціалом взаємодії варто розуміти існуючі резерви та можливості, що виникають у процесі взаємовідносин між елементами системи публічного управління або між підсистемами та можуть бути мобілізовані й спрямовані на трансформацію взаємовідносин у взаємодію задля досягнення певних цілей.

Висновок. Для забезпечення надійності фрункціонування системи взаємовідносин між органами державної влади, місцевого самоврядування та інститутами громадянського суспільства постає необхідність формування адекватного механізму, який дозволить ефективно реагувати 
Схема концепції публічно-партнерської взаємодії в системі публічного управління

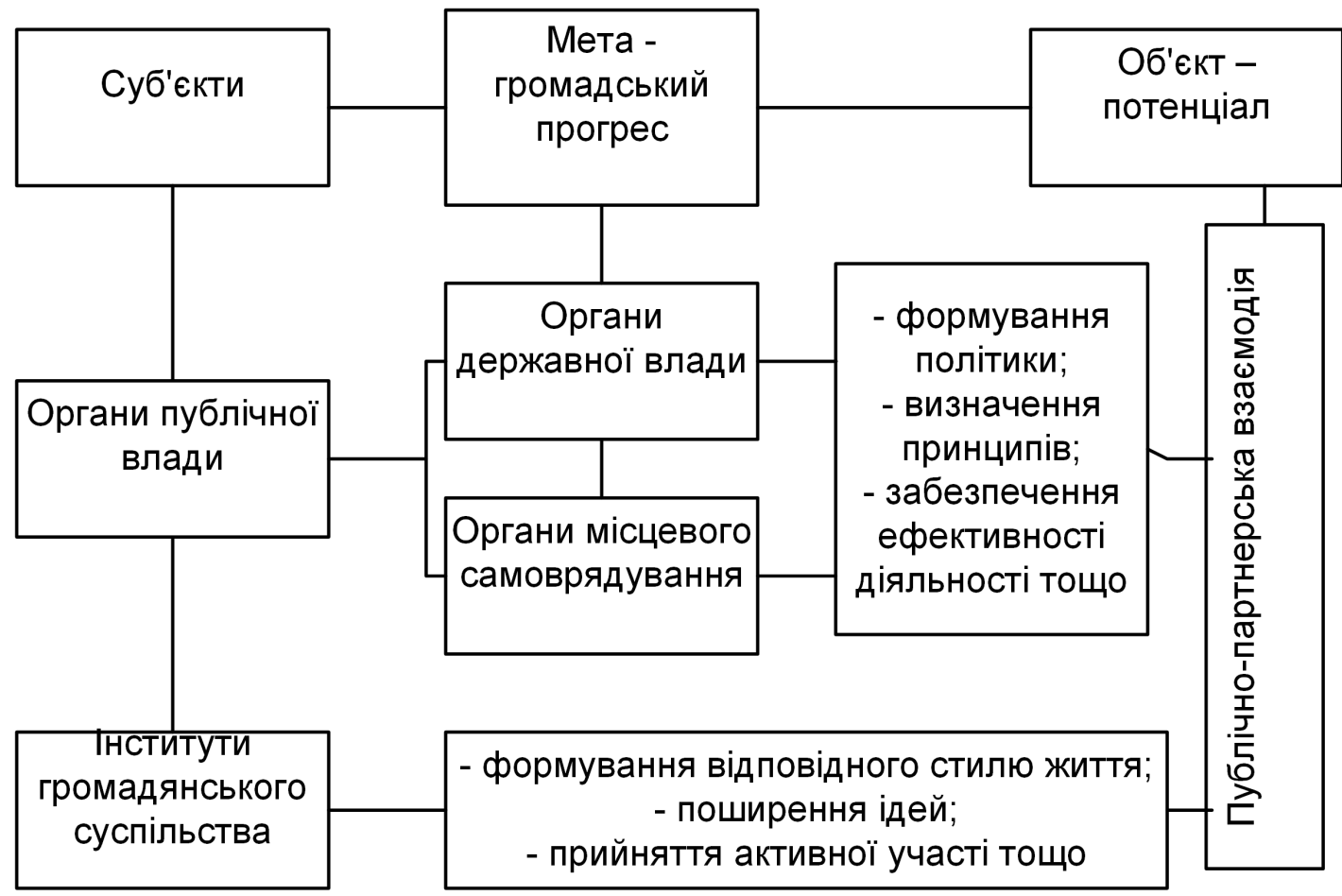

Рис. 4. Формування партнерської взаємодії в системі публічного управління

Джерело: побудовано авторкою[12]

на процеси фрормування публічно-партнерської взаємодії, оскільки безсистемність у взаємодії елементів системи публічного управління здатна блокувати використання наявного потенціалу. Зазначене додатково загострює проблему адаптації публічного управління до зовнішніх змін та не сприяє ефективній взаємодії між державною й суспільством. Тож, система публічного управління потребує розвитку потенціалу взаємодії на партнерських засадах, а сам «потенціал» можна визначити як сукупність ресурсів, що використовуються з метою досягнення необхідного рівня публічно-партнерської взаємодії в інтересах забезпечення її результативності / ефективності.

\section{БІБЛІОГРАФІЧНИЙ СПИСОК:}

1. Халепа О. Формати сучасної взаємодії зі спільнотами. Сучасне мистецтво. 2016. Вип. 12. С. 169-180. URL: http://nbuv.gov.ua/UJRN/S myst 20161219 (дата звернення: 13.08.2021).

2. Вербець В. В., Субот О. А., Христюк Т. А. Соціологія : навчальний посібник. Київ : КОНДОР, 2009. 550 с.

3. Васютинський В. Психологічні виміри спільноти : монографрія. Київ : Золоті ворота, 2010. 120 с.

4. Європейське врядування. Біла книга. 25.7.2001. СОМ (2001) 428. Брюсель. 40 c. URL: http://brdo.com.ua/ wp-content/uploads/2016/01/Bila-knyga-YEvropey-ske-vryaduvannya.pdf (дата звернення: 10.08.2021).

5. Громадянське суспільство в сучасній Україні: специфіка становлення, тенденції розвитку : монографрія / за заг. ред. Ф. М. Рудича. Київ : Парламентське видавництво, 2006. 412 с.

6. Московець В. І. Поняття «громадськість» у законодавстві та адміністративно-правовій теорії. Форум права. 2011. № 2. С. 630-634.

7. Щедрова Г. П. Громадянське суспільство, правова держава і політична свідомість громадян : монографрія. Київ : Ісідо, 1994. 112 с.

8. Тихомирова Є. Б. Зв'язки з громадськістю : навчальний посібник. Київ : НМЦВО, 2001. 560 с.

9. Даниленко Л. І., Поліщук І. В. Перспективи та виклики євроінтеграційних процесів для України : навч.-метод. матеріали. Київ : НАДУ, 2013. 132 с.

10. Собків Я. М. Засади взаємодії інститутів держави і громадянського суспільства в реалізації інформаційних прав і свобод людини і громадянина. URL: https://goal-int.org/zasadi-vzayemodii-institutiv-derzhavii-gromadyanskogo-suspilstva-v-realizacii-informacijnix-prav-i-svobod-lyudini-i-gromadyanina/ (дата звернення: 15.08.2021).

11. Інститути громадянського суспільства та інститут громадських організацій в Україні: теоретико-методологічні та нормопроектні аспект. Офріційний вебсайт Міністерства юстиції України. URL: https://minjust.gov. 
ua/m/str_20126 (дата звернення: 15.08.2021).

12. Михайловська О. В. Концепція громадського прогресу в науці публічного управління : монографія. Мена : ТОВ «Домінант», 2020. 308 с.

13. Сухорольська І. Ю. Громадська дипломатія як чинник демократизації політичної системи України : дис. ...канд. пол. наук : 23.00.02 / Національний університете «Львівська політехніка» Львів. 2015. 205 с.

14. Письменний I. Сутність синергетичного потенціалу публічного управління. URL: http://www.dridu.dp.ua/vi davnictvo/2010/2010_01(4)/10pivppu.pdf (дата звернення: 25.08.2021).

15. Бажинова О. А., Кучабський О. Г. Механізми комунікації влади та громадськості в умовах. Публічне управління: теорія та практика. 2012. № 4 (12). С. 196-201.

\section{REFERENCES:}

1. Khalepa, O. (2016) Khalepa, O. Formaty suchasnoi vzaiemodii zi spilnotamy. [Formats of modern interaction with communities]. Suchasne mystetstvo. Vyp. 12. S. 169-180.URL: http://nbuv.gov.ua/UJRN/S myst 2016 12 19 (Accessed 13.08.2021). [in Ukrainian].

2. Verbets, V. V., Subot, O. A. \& Khrystiuk, T. A. (2009) Sotsiolohiia [Sociology] : navchalnyi posibnyk. Kyiv : KONDOR. 550 s. [in Ukrainian].

3. Vasiutynskyi, V. (2010) Psykholohichni vymiry spilnoty [Psychological dimensions of community] : monohrafiia. Kyiv : Zoloti vorota. 120 s. [in Ukrainian].

4. Yevropeiske vriaduvannia. Bila knyha. [European governance. White book.]. 25.7.2001. SOM (2001) 428. Briusel. 40 s. URL: http://brdo.com.ua/wp-content/uploads/2016/01/Bila-knyga-YEvropey-ske-vryaduvannya.pdf (Accessed: 10.08.2021). [in Ukrainian].

5. Hromadianske suspilstvo v suchasnii Ukraini: spetsyfika stanovlennia, tendentsii rozvytku (2006) [Civil society in modern Ukraine: the specifics of formation, development trends] : monohrafiia / za zah. red. F. M. Rudycha. Kyiv : Parlamentske vydavnytstvo. $412 \mathrm{~s}$. [in Ukrainian].

6. Moskovets, V. I. (2011) Poniattia «hromadskist» u zakonodavstvi ta administratyvno-pravovii teorii. [The concept of "public" in legislation and administrative law theory]. Forum prava. № 2. S. 630-634. [in Ukrainian].

7. Shchedrova, H. P. (1994) Hromadianske suspilstvo, pravova derzhava i politychna svidomist hromadian. [Civil society, the rule of law and the political consciousness of citizens] : monohrafiia. Kyiv : Isido. $112 \mathrm{~s}$. [in Ukrainian].

8. Tykhomyrova, Ye. B. (2001) Zviazky z hromadskistiu. [Public relations] : navchalnyi posibnyk. Kyiv : NMTsVO. 560 s. [in Ukrainian].

9. Danylenko, L. I. \& Polishchuk, I. V. (2013) Perspektyvy ta vyklyky yevrointehratsinykh protsesiv dlia Ukrainy. [Perspectives and challenges of European integration processes for Ukraine] : navch.-metod. materialy. Kyiv : NADU. $132 \mathrm{~s}$. [in Ukrainian].

10. Sobkiv, Ya. M. Zasady vzaiemodiiinstytutiv derzhavy I hromadianskoho suspilstva v realizatsii informatsiinykh pravi svobod liudyny I hromadianyna. [Principles of interaction of institutions of the state and civil society in realization of information rights and freedoms of the person and the citizen]. URL: https://goal-int.org/zasadi-vzayemodii-institutiv-derzhaviigromadyanskogo-suspilstva-v-realizacii-informacijnix-prav-i-svobod-lyudini-i-gromadyanina/. (Accessed: 15.08.2021). [in Ukrainian].

11. Instytuty hromadianskoho suspilstva ta instytut hromadskykh orhanizatsii v Ukraini: teoretyko-metodolohichni ta normoproektni aspekt. [Institutes of civil society and the institute of public organizations in Ukraine: theoreticalmethodological and normative aspect]. Ofitsiinyi vebsait Ministerstva yustytsii Ukrainy.URL: https://minjust.gov.ua/m/ str_20126 (Accessed: 15.08.2021). [in Ukrainian].

12. Mykhailovska, O. V. (2020) Kontseptsiia hromadskoho prohresu v nautsi publichnoho upravlinnia [The concept of social progress in the science of public management] : monohrafiia. Mena : TOV «Dominant». $308 \mathrm{~s}$. [in Ukrainian].

13. Sukhorolska, I. Yu. (2015) Hromadska dyplomatiia yak chynnyk demokratyzatsii politychnoi systemy Ukrainy. [Public diplomacy as a factor of democratization of the political system of Ukraine] : dys. ...kand. pol. nauk : 23.00.02 / Natsionalnyi universytete «Lvivska politekhnika» Lviv. 205 s. [in Ukrainian].

14. Pysmennyi, I. (2009) Sutnist synerhetychnoho potentsialu publichnoho upravlinnia. [The essence of the synergetic potential of public management]. URL: http://www.dridu.dp.ua/vidavnictvo/2010/2010_01(4)/10pivppu.pdf (Accessed: 25.08.2021). [in Ukrainian].

15. Bazhynova, O. A., Kuchabskyi, O. H. (2012) Mekhanizmy komunikatsii vlady ta hromadskosti v umovakh.[ Mechanisms of communication between government and the public in conditions]. Publichne upravlinnia: teoriia ta praktyka. № 4 (12). S. 196-201. [in Ukrainian]. 